International Journal of Business Management and Economic Review

Vol. 4, No. 06; 2021

ISSN: 2581-4664

\title{
THE EFFECT OF UNDERSTANDING OF GOVERNMENT ACCOUNTING STANDARD, LOCAL FINANCIAL ADMINISTRATION, AND THE INTERNAL CONTROL SYSTEM ON THE QUALITY OF FINANCIAL REPORTING OF REGENCY GOVERNMENT WORKING UNIT (SKPK) IN SOUTH ACEH REGENCY, ACEH PROVINCE, INDONESIA
}

\author{
Yulizar, Syukriy Abdullah and Muslim A. Djalil * \\ Magister of Accountancy Program, Faculty of Economics and Business Universitas Syiah Kuala, Banda Aceh, \\ Indonesia \\ http://doi.org/10.35409/IJBMER.2021.3333
}

\begin{abstract}
The purpose of this study is to examine the effect of understanding the government accounting standards the local financial administration, and the internal control system on the quality financial reporting of Regency Service Unit (SKPK) in South Aceh Regency. This quantitative research that employs census causal relationship study has Unit of Analysis of 56 SKPK of with consist of PPKSKPK (Financial Administration Officer of the SKPK), expenditure treasurers, the officials and staffs of the BPKD's accounting department and the Inspectorate's auditors as the respondents. The data collection was carried out by distributing a set of questionnaires to 104 respondents where there are 32 items of questions for all variables studied. The results of research indicated that understanding the government accounting standard, the local financial administration, and the internal control system have a positive effect, simultaneously and partially, on the quality financial reporting of SKPK in the Regency.
\end{abstract}

Keyword: The Government Accounting Standard, The Local Financial Administration, The Internal Control System, Financial Reporting Quality.

\section{INTRODUCTION}

The local financial report is a structured record of information from a reporting entity during an accounting period. The quality of local government financial reporting is highly reliant on the quality of financial reporting of the SKPK. The South Aceh Regency has obtained the Unqualified Opinion (WTP) for the consecutive periods between 2015 to 2018 of financial reports audited by Financial Audit Board (BPK) of the Republic of Indonesia. According to the Director General of Treasury(DJPB) of the Ministry of Finance, Marwanto Harjowiryono, in an interview with Metro TV (24/05/2017), Unqualified Opinion (WTP) reflects the quality of the government financial reporting. This is in line with the opinion of the Director of Accounting and Financial Reporting of the Ministry of Finance, Firmansyah N. Nazaroedin, who stated that the WTP opinion is a description of state financial management that in accordance with the Best Practices. Rini (2014) states that the quality of local government financial reporting is increasing as indicated by the improvement in audit opinion on Regional Government Financial report (LKPD) in Indonesia.

The drafting of LKPD is carried out by consolidating all the SKPK's financial statements. There are some disadvantages and obstacles faced by SKPK in the preparation of financial 


\section{International Journal of Business Management and Economic Review}

Vol. 4, No. 06; 2021

ISSN: 2581-4664

statements, especially on the SKPK level. The related phenomenon on the quality of financial reporting that usually occurred in the South Aceh Regency is typically concerning the uneven distributional knowledge and understanding of SAP (Government Accounting Standard) across all SKPK. Some PPK-SKPK (Finance Administration Officers) have not been able to develop their own financial reports without the assistance of the Regional Financial Management Agency, (BPKD). It occurs due to the lack of skilled employees who understand accounting or staff with Accounting background, low skill level of financial management human resources in SKPK regarding regulatory and administration application. Other reasons include the inadequate complication in financial administration, especially in the administration of assets, administration of inventories, administration of goods and services tax. Additionally, there are demands for refunds and claims for compensation for several SKPK. A weak internal control system is also evident from the overdue of financial report submission by some units.

The relationship between aspects that affect the quality of government financial reports has been studied by Syahputra (2017) in Bener Meriah, concluding that the application of SAP has a positive effect on the quality of SKPK's financial reports. Munasyir (2015) found that SAP had a positive effect on the quality of SKPK's financial reports. This means that if the application of SAP is acceptable then the quality of the resulting report will follow. Rahayu (2014) also concludes that government accounting standards have a significant effect on the quality of financial reports. Nugraheni and Subaweh (2008), as cited by Adhi and Suhardjo (2013), found that the implementation of SAP at the Inspectorate General of the Ministry of National Education had an effect on the quality of the agency's financial reports. Mahaputra and Putra (2014) agreed with the statement saying that SAP had a positive effect on quality as of their report over SKPK in Gianyar district. Susilawati's (2016) proves that the treasurers and financial administration officials play an important role in shaping the quality of local government financial reports in Sigi district. Manuavi et al. (2016) add that the competence of financial administration officials had an influence on the drafting effectiveness of the financial statements in the SKPK of Bireun Regency. Mahaputra and Putra (2014) found that the internal control system had a positive and significant effect on the quality of financial reporting information in SKPK of the Gianyar district. Afiah and Azwari (2015) provide evidence that the implementation of an internal control system from the government has a positive and significant impact on the quality of financial reporting. Several studies conducted by Efendi et al. (2017) and Zainuddin (2020) also provide evidence of the relationship between the government's internal control system and the quality of the financial reports.

This study aims at proving that there is an effect of understanding government accounting standard, the local financial administration, and the internal control systems on the quality of SKPK's financial reporting in South Aceh Regency.

\section{LITERATURE REVIEW}

\subsection{The Financial Report of Local Government}

According to Lillrank (2003), financial report is a structured report concerning the financial status and transactions that were performed and fall under the jurisdiction of reporting section. According to the Institute of Indonesia Chartered Accountants (IAI) (2015: 2), financial report is a part of the financial reporting process. A complete financial report usually comprises of balance sheet, income report, statements of changes in financial status (which are presented in various 


\section{International Journal of Business Management and Economic Review}

Vol. 4, No. 06; 2021

ISSN: 2581-4664

ways such as cash flow statement), notes and other reports as well as other explanatory materials which are an integral part of financial report.

A government financial report should provide information that useful to the users in assessing accountability and making a good decision of economy, social, and politic. The general purpose of financial report is to provide information regarding the financial status, budget realization, cash flow, and the financial performance of a reporting entity that is useful for users in making and evaluating decisions regarding resource allocation (Efendi et al., 2017). According to the Government Regulation (PP) No. 71 of 2010, the preparation of government financial reports is intended to present information that is useful in making decisions and show the accountability of the reporting entity for the resources of which it had been trusted.

According to Salamun (2007), as cited in Efendi et al. (2017), the basic assumption of financial reporting within the government is based on the premises and assumptions that were accepted as truth without proof so that accounting standards can be applied. These assumptions consist of the entity's independency assumption, sustainability assumption, and accrual assumption. In addition, financial reporting ought to have major principles that can be used as provisions to be understood and adhered by the accounting administrators, the reporting personnels, as well as the users of financial reports in carrying out their works. The quality of financial report is very influential on accountability. A good financial report provides dedication on accountability or responsibility upon the prepared report.

The quality of financial report represents the capability to present a good financial report which criteria include: conformity with SAP, adequacy of disclosure, compliance with laws and regulations, and the effectiveness of the internal control system (Yuliani, 2010). The quality of the local government financial report is a sort of public demand to prove a good governance that during the process underwent a paradigm shift and the principles of local financial management, either at the budgeting stage, implementation and accountability (Yusniyar et al., 2016).

The Government Regulation No. 71 of 2010 describes the qualitative characteristics of financial report as normative measures that need to be translated into accounting information so that it can fulfill its objectives. The following four characteristics are the normative prerequisite conditions that needed for government financial report to meet the required quality: (1) relevant, (2) reliable, (3) comparable and (4) understandable.

\subsection{The Government Accounting Standard (SAP)}

The government accounting standards (SAP) is a source of generally accepted accounting reports of government officials to facilitate financial status that exemplify transparency and accountability goals; hence it can be used as a basis for decision making in government. The enactment of Law No. 17 of 2003 on State Finance and the Government Regulation No. 71 of 2010 concerning government accounting standards requires local governments to manage their finances economically, effectively, efficiently, transparently and in accordance with applicable regulations, by making them accountable through financial reports prepared based on generally accepted accounting principles.

The Regulation of the State General Treasury Act No. 1 of 2004 article 51 paragraph (2) provides that, the Head of SKPK as the Budget User must carry out accounting on financial transactions, assets, debts, and equity including the revenue and expenditure transactions which are under his/her responsibility. This means that each SKPK is required to prepare a work unit 


\section{International Journal of Business Management and Economic Review}

Vol. 4, No. 06; 2021

ISSN: 2581-4664

financial report consisting of: (1) the Statement of Budget Realization (LRA), (2) the Operational Report, (3) the Balance Sheet, (4) the Statement of Change in Equity, and (5) the Notes to the Financial Statements, while the Cash Flow Statement is prepared by the Head of the Local Financial Management Unit as the Local General Treasurer.

According to Adhi and Suhardjo (2013), the government accounting standards regulate the presentation of financial reports for general purposes in order to improve the comparability of financial reports both for the budgets, between periods, and between entities. Zeyn (2011) notes that government accounting standards establish all considerations within the framework of the presentation of financial reports, the guidelines for the structure of financial reports and the minimum requirements for the contents of financial reports.

The government accounting standards require every reporting entity, including the local governments, to report the efforts that have been made and the results achieved in implementing activities in a systematic and structured manner during a reporting period for the purposes of accountability, management, transparency, and balance between generation and performance assessment. The usefulness of financial statements is determined by the content of the information presented in the financial statements. To ensure that the reports contain meaningful information and useful, the financial statements ought to be prepared according to government accounting standards.

\subsection{The Local Financial Administration}

The local financial administration is the bookkeeping records that show a series of information and activities carried out in the financial sector based on certain principles, standards and procedures so as to provide actual information in the field of local finance (Ratih 2012). It's a characteristic associated with the PPK-SKPK which reflects the knowledge, skills, and attitudes in the realization of their official positions (Manuavi, 2016).

This sector is an inseparable part of the local financial management process, both according to Government Regulation No. 58 of 2005 and based on the Regulation of the Minister of Home Affairs (Permendagri) No. 13 of 2006 based on the Guidelines for Regional Financial Management. A description of local financial administration includes the following: (a) the general principles of local financial administration; (b) the implementation of local financial administration; (c) the administration of revenue; and (d) the administration of expenditures.

According to the explanation from the Regulation of the Minister of Home Affairs (Permendagri) No. 13 of 2016, the SKPK Financial Administration Officers, hereinafter abbreviated as the PPK-SKPK, are officials who carry out financial administration functions at the SKPK. Together with the revenue treasurer, the expenditure treasurer, asset manager, and the executive staff, the SKPK financial administration officials complete their own tasks in preparing the reports within the appointed time and in accordance with applicable regulations.

In the South Aceh Regency, the District Regulation No. 65 of 2016 about the accounting systems of the South Aceh Regency Government serves as the guidelines in implementing local financial administration, the explanation in which can be seen in appendix one to appendix three. The regulation itself oversees the accounting system in the District Finance Administration Office (PPKD), that consist of the income accounting - LO and Income Statement of Budget Realization (LRA), the expense and expenditure accounting, the transfer accounting, the cost accounting, the asset investment accounting, the liability accounting, the 


\section{International Journal of Business Management and Economic Review}

Vol. 4, No. 06; 2021

ISSN: 2581-4664

correction and adjustment journals, the journals, the general ledgers and the cash balance, the preparation of financial reports, and the preparation of local government consolidated financial report.

Appendix 2 describes the accounting system in SKPK which comprise the income accounting of the Operational Report (LO) and the income accounting of the Statement of Budget Realization (LRA), the expense and expenditure accounting, the receivables accounting, the inventory accounting, the fixed-asset accounting, the other asset accounting, the liability accounting, the equity accounting, the general ledger journals and the last balance sheets of the SKPK's financial statements preparation.

Furthermore, the South Aceh Regency had established the Regional Provision (Qanun) of South Aceh Regency No. 4 of 2015 about the amendments on the Qanun No. 8 of 2008 concerning the principle of local financial administration as a guideline for the financial accountability of local financial management, which becomes one of the guidelines for local financial administration.

\subsection{The Government's Internal Control System}

The internal control system is an integrated process of actions and activities carried out continuously by the head of departments and all employees to provide a satisfactory guarantee on the achievement of organizational goals through effective and efficient activities, reliability of the financial reporting, protection of the state assets, and in compliance with laws (government regulation No. 60 of 2008 pertaining to SPIP). A SPIP with high level inadequacy will affect the quality of local government's financial reports. The higher the limitation, the lower the quality of LKPD (Sarwono et al., 2018).

The internal control system is policies and procedures that are implemented to obtain assurance that the specific objectives of a business unit will be achieved (Arens et al., 2006). Rai (2008: 283) explains that the internal control system is a policy and procedure designed to provide adequate confidence for management in regard that the organization can achieve its goals and objectives. According to Petrovits et al. (2010), the internal control system of financial reporting is a process undertaken by management to provide assurance for the company in which the corporation will be able to achieve its goals effectively and efficiently. A reliable financial statement that is in compliance with laws and regulations.

The Committee of Sponsoring Organizations of the Trade way Commission (COSO) defines the internal control system as an influenced process to provide assurance that organizational goals can be achieved through: an effective and efficient operational, a reliable presentation of financial statements, in compliance with the laws and rules. According to COSO, the components of internal control system consist of: control environment, financial risk assessment, control activities, information and communication, and monitoring. The internal control system itself must be monitored on a regular basis. Should a significant deficiency occurred, it must be reported to the upper management section and to the board of commissioners. This policy model can also be applied to the public sector.

The internal control system consists of policies and procedures that employed to guarantee the goals are achieved or to provide reliable financial information, as well as to guarantee compliance with laws and regulations. The control procedures are established to standardize work processes, so as to ensure the achievement of organizational goals and to prevent or to detect problems. According to Wilkinson et al. (2000), as cited in Indriasari (2008), the sub- 


\section{International Journal of Business Management and Economic Review}

Vol. 4, No. 06; 2021

ISSN: 2581-4664

components of control activities that related to financial reporting are: (a) an adequate design and the use of documents and records that labeled with accession number, (b) the distribution of duties, (c) an adequate authorization on transactions, (d) an independent examination of the performance, and, (e) a a proper assessment over the recorded number.

The research conducted by Mulyani and Suryawati (2011) concluded that the internal control system has an important role in minimizing misstatements in local government financial reports hence it will be able to provide an accurate and precise information. In their research, Fatmawati and Setiawan (2018) offer the insight as to why it is important to have internal supervision within the local government sector. Yamamoto (2008) explained the essential factor and the usefulness the internal control system plays for financial information in the internal decision making. Noguiera and Jorge (2012), as cited in Fatmawati and Setiawan (2018), concluded that most of the respondents in the city of Braganca agree that the internal control system of financial information is important in making decisions seeing as it contributes to the improvement of the reliability of financial information and enables the information to be presented in timely manner. In her research, Sari (2012) aimed to provide assurance that the local financial reports are presented fairly in accordance with the accounting principles, in compliance with regulations, and operational effectiveness.

The internal control system is useful and functional in making decision. All operations, physical resources, and data can be monitored and controlled which result in the achievement of goals and presentation of better-quality information. In addition to the national rules, the internal control system in the South Aceh Regency also follows the systems and procedures of financial management and its accountability. Both of these system and procedure are legalized by the head of the region, in this case the Head of the South Aceh Regency.

\subsection{Research Hypothesis}

According to Sugiyono (2013: 128), the theoretical framework corresponds with the independent and the dependent variable. The following describes a research framework regarding the influence of government accounting standard, the local financial administration, and the internal control system on the quality of financial reporting in South Aceh Regency.

\subsubsection{The Effect of Understanding the Government Accounting Standard on the Quality of Financial Reporting.}

According to Mahmudi (2011: 271), accounting standard can improve the quality of financial report in terms of its consistency, comparability, understanding, relevancy and reliability. The attempts to improve the quality of local government financial reports in Indonesia require prerequisite conditions that incorporate juristical mark in the form of government accounting standards.

Adhi et al. (2013) and Rahayu et al. (2014) pointed out that the implementation of government accounting standards has an impact on improving the quality of financial reporting in the central and local governments. This is in line with the Government Regulation No. 8 of 2006 as cited in Susilawati and Riana (2014) who said that financial reports must be presented in accordance with government accounting standards. Yuliani (2010) reported that compliance with government accounting standards is one of the criteria for good financial reports. Syahputra (2017), Mahaputra and Son (2014), Munasyir (2015), and Rahayu (2014), concluded that the 


\section{International Journal of Business Management and Economic Review}

Vol. 4, No. 06; 2021

ISSN: 2581-4664

implementation of SAP presents a positive and significant impact on the quality of the SKPK's financial statements. The first hypothesis can be made as follows:

H1: Understanding the government accounting standards affects the quality of SKPK's financial reporting in the South Aceh Regency

\subsubsection{The Effect of Local Financial Management Administration on the Quality of Financial Reporting}

The relationship between financial administration and financial reporting has been studied by Susilawati (2016) and Manuavi et al. (2016). Susilawati's (2016) proved that the treasurers and financial administration officials play an important role in shaping the quality of local financial reports in Sigi district. Manuavi et al. (2016) found out that the competence of financial administration officials had an impact on the effectiveness of the financial reports' preparation in the SKPK of Bireun Regency.

Efendi et al. (2017) and Manuavi et al. (2016) agreed that officials with high level competence on the subject provide positive outcome on the quality of regional financial reporting in SKPK. It can be presumed that financial administration did affect the quality of SKPK's financial reporting, hence the second hypothesis were formulated as follow:

$\mathrm{H} 2$ : The local financial administration affects the quality of SKPK's financial reporting in the South Aceh Regency.

\subsubsection{The Effect of Internal Control System on the Quality of Financial Reporting.}

Andrianto (2017) stated that the internal control system significantly affects the quality of financial reports. As an operational process that is carried out by the board of commissioners, the management team, and other personnel of the entities, the internal control system is specifically designed to provide a sense of assurance of achieving specified objectives. Arens et al. (2008: 290), and Susilawati et al. (2014) declared that an effective financial internal control can improve the quality of financial reporting.

Mahaputra and Putra (2014) found that the internal control system has a positive and significant effect on the quality of financial reporting information in the SPPK of Gianyar District. Reports proofed that the implementation of internal control system has a positive and significant impact on the quality of financial reporting (Afiah and Azwari, 2015). Improving the government's internal control system plays a very important role for the quality of financial reporting in local government. Another report on the significantly positive effect offered by excellent internal control system on financial reporting took place in Aceh Jaya (Zainuddin, 2020). Several studies conducted by Efendi et al. (2017) also provide evidence of the relationship between the government's internal control system and the quality of financial reports. The third hypothesis can be made as follows:

H3: The internal control system affects the quality of SKPK's financial reporting in the South Aceh Regency 


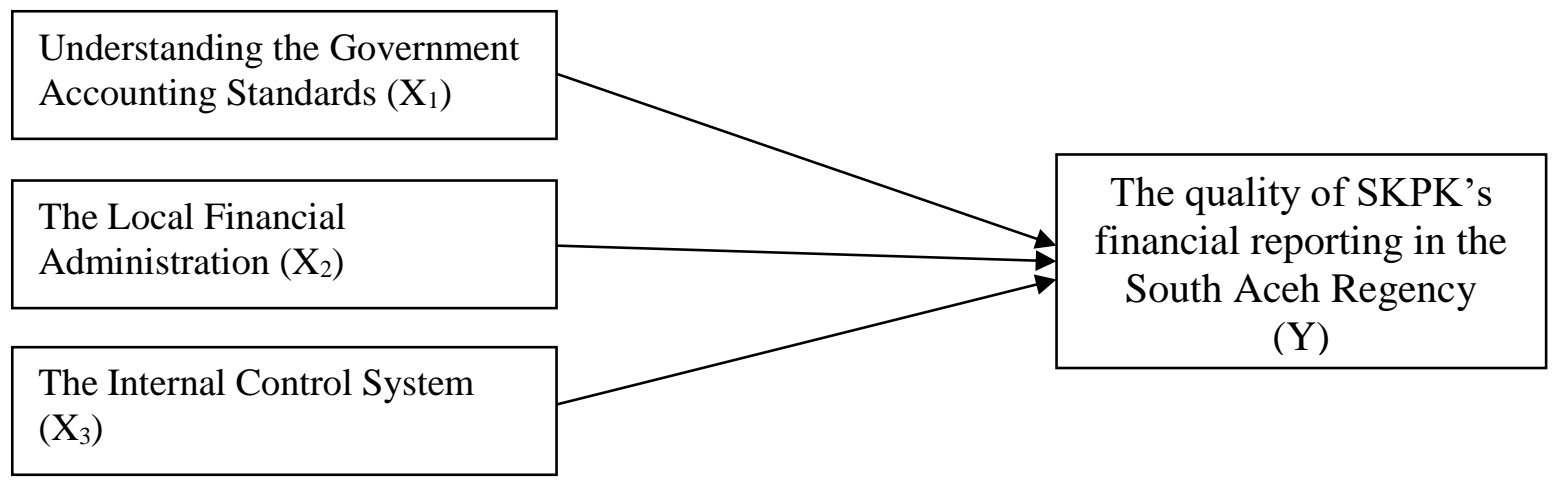

Picture 1. The scheme of the theoretical framework

\section{RESEARCH METHOD}

\subsection{Research Design}

This study aims to determine the relationship between variables in a hypothesis testing, which is to understand the implication of understanding the government accounting, local financial administration and the internal control systems on the quality of SKPK's financial reporting in the South Aceh Regency. The study utilizes the quantitative approach with the statistical techniques based on the census method of causal relationship study. It was used to see the causes and effects of understanding the government accounting, the local financial administration and the internal control systems on the quality of SKPK's of financial reporting in the South Aceh Regency by using a quantitative approach with statistical techniques. The main focus of analysis in this study occurred on the organizational level.

Cross sectional studies were used for the timeframe in the data collection, in which the data were collected only in one occasion within a period of time to answer the research questions by collecting questionnaire responses from each respondent.

\subsection{Population and Sample}

A total of 56 SKPKs in the South Aceh Regency with 132 respondents were selected. The sample consists of the PPK, the expenditure treasurers, the officials and staff of the BPKD accounting department and the inspectorate auditors. The research used the census method, where the samples of the research comprise of all members of the population.

\subsection{Techniques and Sources of Data Collection}

This study uses both primary and secondary data to present and support the overall results. The earlier was obtained from the results of questionnaires from the respondents, while the latter was research on the government regulations, journals and previous research. The data were collected by distributing the questionnaires to all respondents within a certain time frame.

\subsection{Operational and Variable Measurement}

The dependent variable in this study is the quality of SKPK's financial reporting in the South Aceh Regency. The indicators to measure the quality of financial reporting are: the level of relevance, the level of reliability, the level of dependability, and the level of understanding. 


\section{International Journal of Business Management and Economic Review}

Vol. 4, No. 06; 2021

ISSN: 2581-4664

Meanwhile, the independent variables are made up of:

1. Understanding the government accounting standards. The indicators consist of the conceptual framework, the components/elements of the financial reports, the recognition elements of financial reports, and the recognition components of financial reports.

2. The local financial management administration. The indicators for this variable include comprehensiveness, accuracy, verification skills, and accounting skills.

3. The internal control system. The indicators to measure this variable are control environment, financial risk assessment, control activities, information and communication, and monitoring.

The five-point Likert scale model was used to measure the interval of each variable. To determine the score, the participants' responses of each statement in the questionnaire were measured by scale, starting from Strongly Agree $(\mathrm{SA})=5$, Agree $(\mathrm{A})=4$, Neutral $(\mathrm{N})$ Partially Disagree $(\mathrm{PD})=3$, Disagree $(\mathrm{D})=2$, and Strongly Disagree $(\mathrm{SD})=1$.

\subsection{Data Analysis and the Hypothesis Testing Design}

In this study, the data were systematically analyzed and processed with the help of the IBM SPSS.22 statistical application using descriptive statstic analysis, data quality checks, and classical assumption tests. After it was confirmed that no bias data were found, the next step of data processing is data testing. The test itself includes the multiple regression analysis in order to assess the relationship between two or more independent variables $(\mathrm{X} 1, \mathrm{X} 2, \mathrm{X} 3)$ with the dependent variable $(\mathrm{Y})$.

The equation for multiple linear regression analysis used in this study is as follows:

$\mathrm{Y}^{\prime}=\mathrm{a}+\beta 1 \mathrm{X} 1+\beta 2 \mathrm{X} 2+\beta 3 \mathrm{X} 3+\mathrm{e}$

\section{RESULTS AND DISCUSSIONS}

\subsection{The Overview of Research Observation}

The unit of analysis in this study is the Regional Service Unit (SKPK) of the South Aceh Regency, which consists of 56 SKPKs. The respondents are those of the PPK and the expenditure treasurers of SKPK, the officials and staff in the accounting section of the Regional Financial Management Agency as well as auditors from the Inspectorate of the South Aceh Regency. A set of 132 questionnaires were distributed to 56 SKPK and only 104 of those were returned for analysis while the rest of 28 sets were not.

\subsection{Descriptive Statistical Analysis}

A descriptive statistical analysis was carried out for each research variable, namely the quality of financial reporting (Y), understanding the government accounting standards (X1), THE local financial administration (X2) and the internal control system (X3). The purpose is to get a prior picture of the mean, the standard deviation, the amount of data, and the maximum and minimum values of each variable in this study. The table below (Table 1) presents the results of the descriptive analysis of the research variables may be seen on the Table 1 below:

\section{Table 1. Descriptive Statistics}


International Journal of Business Management and Economic Review

Vol. 4, No. 06; 2021

ISSN: 2581-4664

\begin{tabular}{|l|l|l|l|l|l|}
\hline No. & Variable Name & Average & Std. Deviation & Minimum & Maximum \\
\hline 1 & $\begin{array}{l}\text { SKPK Financial Reporting } \\
\text { Quality (Y) }\end{array}$ & 33.88 & 2,765 & 27 & 40 \\
\hline 2 & $\begin{array}{l}\text { Understanding } \\
\text { Government Accounting } \\
\text { Standards (X1) }\end{array}$ & 33.62 & 2,689 & 29 & 40 \\
\hline 3 & $\begin{array}{l}\text { The Local Financial } \\
\text { Administration (X2) }\end{array}$ & 25.73 & 3,141 & 14 & 30 \\
\hline 4 & $\begin{array}{l}\text { The Internal Control System } \\
\text { (X3) }\end{array}$ & 41.50 & 4,094 & 28 & 50 \\
\hline
\end{tabular}

Source: The Results of Primary Data Processing (2020)

\subsection{The Results of the Research Instrument Testing}

4.3.1 Validity and Reliability Test

The Pearson Product Moment Coefficient of Correlation was used to test the validity of the instrument. Based on the output of the SPSS application, out of 32 statements, all of them are valid, where the correlation coefficient, r-value, from each statement is above the r-table or the critical value of the product moment correlation. The critical value is $5 \%$ with $\mathrm{N} 104=0.176$, provided the correlation value is greater than the critical value, the statements are significant and valid.

The validity test results of each questionnaire from the quality of SKPK's financial reporting variable (Y), understanding the government accounting standards (X1), the local financial administration (X2), and the internal control system (X3) are above the critical value of the product moment (correlation coefficient > 0.176) hence that the questionnaire used is valid.

Meanwhile, the Cronbach's Alpha was used to test the reliability of the instrument. The results for the four variables are Y (0.792), X1 (0.775), X2 (0.895), and X3 (0.894) where Cronbach's Alpha was greater than 0.7. This shows that the instrument in this study is reliable, so it can be concluded that the questionnaire, which is the measurement tool in this study, is reliable and feasible to use.

\subsection{The Result of the Classic Assumption Testing 4.1.1. Multicollinearity Test}

This test was carried out to avoid the multicolinearity between the independent variables in the regression model. Whether or not the multicollinearity between variables existed, it can be checked in the the tolerance value and the variance inflation factor (VIF).

The tolerance value from each three variables, understanding the government accounting standards (X1), the local financial administration (X2), and the internal control system (X3), is > 0.10 which indicates that there were no multicolinearity between independent variables. Furthermore, the results of the VIF value also show that there are no independent variables with a VIF value >10. It can be concluded that there were no multicolinearity between the independent variables in this study.

\subsubsection{Normality Test}

The normality test was used to determine whether both the independent and dependent 


\section{International Journal of Business Management and Economic Review}

Vol. 4, No. 06; 2021

ISSN: 2581-4664

variables are normally distributed in this regression model. A good regression model is one that does not have the heteroscedasticity in it. The Scatter Plot diagram was used to display the heteroscedasticity point, in which the random disturbance of plots scattered across the vector and that far of zero value, which means no heteroscedasticity occurred.

\subsubsection{Heteroscedasticity Test}

This test is carried out to determine whether there is an inequality of variance from the residuals of one observation to another in a regression model. A good regression model is one that does not have heteroscedasticity result. This study adopted the Scatter Plot diagram to test the heteroscedasticity assumption in which the points spread irregularly around the zero value, meaning that heteroscedasticity does not occur.

\subsection{The Result of the Hypothesis Testing}

Based on the SPSS statistical analysis, the data processing results generate the following regression equation:

$$
\mathrm{Y}=5.012+0.450 \mathrm{STD}+0.203 \mathrm{PKD}+0.205 \mathrm{SPI}+e
$$

It can be concluded that:

1. The constant $=5.012$ with a positive value. It reflects the positive influence of all three independent variables, which are: understanding the government accounting standards, the local financial administration, and the internal control system. This means that if the independent variable increases by one point then the dependent variable, namely the quality of financial reporting, will increase by 5.012 units on an interval scale.

2. The regression coefficients for the STD, PKD and SPI variables are 0.450, 0.203, and 0.205 , respectively. All three results represent positive correlation. It points out the regression coefficient of $\beta \neq 0$, which means that the results of the study accept the hypothesis. To conclude, understanding the government accounting standards, the local financial administration, and the internal control system have positive influences on the quality of SKPK's financial reporting. Furthermore, it can be translated that every time there is an increase in understanding the government accounting standards, the local financial administration and the internal control systems by 1 unit, it will also improve the quality of SKPK's financial reporting by $0.450,0.203$ and 0.205 unit on the interval scale. Thus, the better in understanding the government accounting standards, the local financial administration and the internal control systems, the better the quality of SKPK's financial reporting. It is in detail can be observed on the following Table 2 below:

Table 2 The Result of Multiple Regression Analysis 


\section{International Journal of Business Management and Economic Review}

Vol. 4, No. 06; 2021

ISSN: 2581-4664

\begin{tabular}{|l|l|l|l|l|}
\hline Equation $\mathrm{y}=$ & $5,012+$ & $0,450 \mathrm{STD}+$ & $0,203 \mathrm{PKD}+$ & $0,205 \mathrm{SPI}$ \\
\hline $\mathrm{t}$-value $=$ & & 6,286 & 2,901 & 3,719 \\
\hline Sig. value $=$ & & 0,000 & 0,005 & 0,000 \\
\hline Alpha level $=$ & 0,792 & 0,775 & 0,895 & 0,894 \\
\hline Tolerance $=$ & & 0,554 & 0,425 & 0,403 \\
\hline $\mathrm{VIF}=$ & & 1,805 & 2,355 & 2,482 \\
\hline $\mathrm{R}=$ & $0,855^{\mathrm{a}}$ & & & \\
\hline $\mathrm{R}^{2}=$ & 0,731 & & & \\
\hline F-value $=$ & 20,432 & & & \\
\hline Sig F $=$ & 0,000 & & & \\
\hline F-table $=$ & 2,670 & & & \\
\hline t-table $=$ & 1,983 & & & \\
\hline
\end{tabular}

Source: The Results of Primary Data Processing (2020)

\subsubsection{Partial Hypothesis Testing}

The hypothesis testing $(\mathrm{H} 1, \mathrm{H} 2, \mathrm{H} 3)$ : If the sig. value $<0.05$ or if $\mathrm{t}$-value $>\mathrm{t}$-table, then there is an influence of $\mathrm{X}$ variable on $\mathrm{Y}$ variable. On the other hand, if the sig. value $>0.05$ or if $\mathrm{t}$-value $<\mathrm{t}$-table, then there is no influences of $\mathrm{X}$ variable on $\mathrm{Y}$ variable. It is understood that the sig. value $(\mathrm{H} 1, \mathrm{H} 2, \mathrm{H} 3)<0.05$ and t-value $(\mathrm{H} 1, \mathrm{H} 2, \mathrm{H} 3)>\mathrm{t}$-table is 1.983 , which means that the H1, H2, and $\mathrm{H} 3$ are accepted. It can be concluded that understanding the government accounting standards, the local financial administration, and the internal control system are partially influence the quality of SKPK's financial reporting in the South Aceh Regency.

\subsubsection{Multiple Hypothesis Testing}

The fourth hypothesis (H4) stated that multiple testing between understanding the government accounting standards, the local financial administration, and the internal control systems affect the quality of SKPK's financial reporting. The test is carried out based on the simultaneous significance test (F-test) to determine whether the multiple tests between independent variables affect the dependent variables. If the sig. value $<0.05$, or F-value $>\mathrm{F}-$ table then there is a simultaneous influences of $\mathrm{X}$ variable on $\mathrm{Y}$ variable whereas if sig. value > 0.05 or $\mathrm{F}$-value $<\mathrm{F}$-table then there is no simultaneous influences of $\mathrm{X}$ variable on $\mathrm{Y}$ variable. The result of F-test is F-table $=2.67$ for the total sample ( $\mathrm{N}$ : 104 with 3 dependent variables) and Fvalue $=20.432$, and the sig. value is 0.000 . The sig. value is $0.000<0.05$ or $20.432>2.67$. It can be concluded that $\mathrm{X}$ variable simultaneously affects $\mathrm{Y}$ variable. It means that understanding government accounting standards, regional financial management administration, and the internal control systems simultaneously influence the quality of SKPK's financial reporting.

Additionally, the coefficient of determination $\left(\mathrm{R}^{2}\right)$ was carried out to support the F-test in order to measure how accurate the test model in reading the dependant variables. It was informed that the coefficient of determination is between 0 and 1 . The value that close to 1 means that the independent variable $(\mathrm{X})$ provides almost all information needed to predict the variation of the 
International Journal of Business Management and Economic Review

Vol. 4, No. 06; 2021

ISSN: 2581-4664

dependent variable $(\mathrm{Y})$. The $\mathrm{R}^{2}$ value is 0.731 meaning that the independent variables provide information needed to predict the variation of $\mathrm{Y}$ variable by 73.10 percent.

\section{CONCLUSIONS AND RECOMENDATIONS}

\subsection{Conclusion}

Understanding the government accounting standard, the local financial administration, and the internal control system have a simultaneous and partial influence on the quality of SKPK's financial reporting in the South Aceh Regency.

\subsection{Recommendations \\ Operational Practices:}

1. The Regency especially the policy makers should employ professional accountants to manage the local financial administration in every SKPK in order to improve the quality of financial reporting

2. Providing training and technical guidance for all human resources in order to increase the quality of financial administration. Furthermore, it helps the employees learn and understand the operational process of government accounting standards and how it should be applied in the process of preparing financial reports.

3. Every problem, difficulty, and weakness in the internal control system should be processed, discussed, and solved as to find a correct solution as well as providing penalty to avoid the same errors.

\subsection{Theoretical Enhancement}

1. This study can be used as a basic description of the many aspects that influence and affect the financial reporting of SKPK. However, the consistency of the research in relation of understanding the government accounting standard, the local financial administration, and the internal control system on the quality of SKPK's financial reporting is possible to be tested by adding another variable. A new variable, such as the information technology implementation variable, is thought to have new and further effect on improving the quality of financial report that may be providing a better and higher quality of report.

2. A broader topic of the study can be conducted by adding the number of population and sample, such as the Budget User, the Revenue Treasurer, the Technical Activity Acting Officer, the Assets Manager, and other parties that associated with the process of financial report preparation. The result can be used to generalize the final result of a study on the higher level.

3. A further research can be conducted by adding another process of data collection, such as the in-depth interview method. As such, it is expected to be able to provide better explanation of the quality of SKPK's financial reporting.

\section{REFERENCES}

Adhi, Daniel Kartika dan Suhardjo, Yohanes., 2013. Pengaruh Penerapan Standar Akuntansi Pemerintahan dan Kualitas Aparatur Pemerintah Daerah terhadap Kualitas Laporan Keuangan (Studi Kasus Pada Pemerintah Kota Tual) Jurnal Stie Semarang, 5 (3): 93-111. 


\section{International Journal of Business Management and Economic Review}

Vol. 4, No. 06; 2021

ISSN: 2581-4664

Afiah, Nunuy Nur dan Azwari, Peny Cahaya. 2015. The Effect of the Implementation of Government Internal Control System (GICS) on the Quality of Financial Reporting of the Local Government and Its Impact on the Principles of Good Governance: A Research In District, City, And Provincial Government In South Sumatera. Procedia Social and Behavioral Sciences 211: $811-818$.

Agung Rai, I Gusti. 2010. Audit Kinerja Pada Sektor Publik. Jakarta: Selemba Empat.

Andrianto, Elvin. 2017. Pengaruh Kapasitas Sumber Daya Manusia, Pemanfaatan Teknologi Informasi, dan Sistem Pengendalian Intern Pemerintah terhadap Kualitas Laporan Keuangan Pemerintah Daerah dengan Komitmen Organisasi sebagai Variabel Moderasi (Studi Empiris pada Satuan Kerja Perangkat Daerah di Kabupaten Sleman). Jurnal Profita Kajian Ilmu Akuntansi. 6 (3).

Arens, et al., 2006. Auditing dan Pelayanan Verifikasi. Edisi 9. Jakarta: PT Indeks.

Arsyiati, Darwanis., dan Djalil, Muslim A. 2008. Pengaruh Kualitas Sumber Daya Manusia dalam

Pengelolaan Keuangan terhadap Kualitas Pertanggungjawaban Keuangan PNBP Dalam Upaya Meningkatkan Kinerja Instansi pada Universitas Syiah Kuala. Jurnal Telaah \& Riset Akuntansi.1 (1): 29-49.

Djalil, Muslim. A., Nadirsyah, S. E., Yahya, M. Rizal., Jalaluddin., dan Ramadhanti, Syarifah Vivi. 2017. The Effect of Used Information Technology, Internal Control, and Regional Accounting System on the Performance of City Governance Agency of Banda Aceh City, Indonesia. BRAND. Broad Research in Accounting, Negotiation, and Distribution.8 (1). ISSN 2067-8177.

Efendi, Loli., Darwanis. dan Abdullah, Syukry. 2017. Faktor-faktor yang mempengaruhi kualitas pelaporan keuangan daerah (studi pada Satuan Kerja Perangkat Kabupaten Aceh Tengah), Jurnal Perspektif Ekonomi Darussalam, 3 (2): 84-185.

Fatmawati, Ratna dan Setiawan, Doddy. 2018. Dampak Pengendalian Intern dan Ketepatan Informasi Terhadap Kebermanfaatan Akuntansi Akrual: Studi pada Pemerintah Daerah. Jurnal Dinamika Akuntansi dan Bisnis. 5 (2):137-150.

Ikatan Akuntan Indonesia. 2011. Standar Akuntansi Keuangan. Jakarta: Salemba Empat.

Ikatan Akuntan Indonesia. 2015. Pernyataan Standar Akuntansi Keuangan. Jakarta: Salemba Empat.

Indriasari, Desi dan Ertambang, Nahartyo (2008). Pengaruh Kapasitas Sumberdaya Manusia, Pemanfaatan Teknologi Informasi dan Pengendalian Intern Akuntansi terhadap Nilai Informasi Pelaporan Keuangan Pemerintah Daerah. Kumpulan Artikel Simposium Nasional Akuntansi (SNA) XI Pontianak.

Kementerian Keuangan RI. 2017. WTP (harusnya) Bukan Sekedar Opini. Treasuri Indonesia. https://djpb.kemenkeu.go.id/portal/images/mti/mti4_2017.pdf

Lillrank, P. 2003. The quality of information. International Journal of Quality \& Reliability Management, 20 (6): 691-703.

Mahaputra dan Putra. 2014. Analisis Faktor yang Mempengaruhi Kualitas Informasi Pelaporan Keuangan Pemerintah Daerah. Jurnal Akuntansi Universitas Udayana. 8 (2).

Mahmudi. 2011. Akuntansi Sektor Publik. Yogyakarta: UUI Press.

Mardiasmo. 2002. Akuntansi Sektor Publik. Yogyakarta: Andi Offset.

Mulyani, Pujianik dan Suryawati, Rindah F, 2011. Analisis Peran Fungsi Sistem Pengendalian Intern Pemerintah (SPIP/PP No. 60 Tahun 2008) dalam Meminimalisasi Tingkat salah Saji 


\section{International Journal of Business Management and Economic Review}

Vol. 4, No. 06; 2021

ISSN: 2581-4664

Pencataan Akuntansi Keuangan Pemerintah Daerah. Jurnal Organisasi Manajemen. 7 (2): $102-116$.

Munasyir. 2015. Pengaruh Penerapan Standar Akuntansi Pemerintahan dan Sistem Pengendalian Intern Terhadap Kualitas Laporan Keuangan SKPD Kabupaten Aceh Utara. Jurnal Administrasi Akuntansi. 4 (4). ISSN 2302-0164: 23-35.

Nogueira, S. P., dan Jorge, S. M. (2012). Adequacy of the Local Government financial reporting model in the context of internal decisionmaking: An exploratory study in the municipality of Bragança. Tékhne - Review of Applied Management Studies. 10(2): 74-86.

Peraturan Pemerintah Nomor 60 Tahun 2008 tentang Sistem Pengendalian Intern Pemerintah.

Peraturan Pemerintah Republik Indonesia Nomor 58 Tahun 2005 tentang Pengelolaan Keuangan Daerah.

Peraturan Pemerintah Republik Indonesia Nomor 71 tahun 2010 tentang Standar Akuntansi Pemerintahan.

Petrovits, Christine., Shakespeare, Catherine dan Shih, Aimee. 2010. The Causes and Consequences of Internal Control Problems in Nonprofit Organizations. Available at SSRN: https://ssrn.com/abstract=1582765

Rahayu, Liza dan Kennedy Yuneita Anisma. 2014. Pengaruh Kompetensi Sumber Daya Manusia (SDM), Penerapan Sistem Akuntansi Keuangan Daerah, dan Penerapan Standar Akuntansi Pemerintah (SAP) terhadap Kualitas Laporan Keuangan Daerah pada Pemerintah Provinsi Riau: Studi Empiris Pada SKPD Provinsi Riau. Jom Fekon. 1(2): 1-15.

Ratih, Asri Eka. 2012. Pengaruh Pemahaman Sistem Akuntansi Keuangan Daerah, Penata-usahaan Keuangan Daerah dan Pengelolaan Barang Milik Daerah terhadap Kinerja SKPD pada Pemerintah Provinsi Kepulauan Riau. Tesis. Medan. Program Pasca Sarjana. Universitas Sumatra Utara.

Rini, Adhariani Sarah. 2014. Opini Audit Dan Pengungkapan Atas Laporan Keuangan Pemerintah Kabupaten Serta Kaitannya Dengan Korupsi Di Indonesia. Jurnal Etikonomi.13 (1): 1-20.

Salamun, Suyono.2007. Analisis Laporan Keuangan Daerah. http://www.google.com

Sari, Purnama Astuti. 2012. Pengaruh Sumber Daya Manusia, Pemanfaatan Teknologi Informasi

Dan Pengendalian Intern Terhadap Kualitas Dan Ketepatwaktuan Pelaporan Keuangan

Pemerintah Kota Dan Kabupaten. Jurnal Akuntansi Universitas Muhammadiyah. Surakarta. Sugiyono. (2013). Metode Penelitian Kuantitatif, Kualitatif dan R\&D. Bandung: Alfabeta. CV

Sarwono, Sunarti Aris .Eddy dan Rahmawati. 2018. Sistem Pengendalian Intern Pemerintah (SPIP), Ketidakpatuhan Regulasi Dan Kualitas Laporan Keuangan Pemerintah Daerah. Jurnal Ekonomi Paradigma. 19 (02).

Susilawati, dan Riana, Dwi Seftihani. 2014. Standar Akuntansi Pemerintahan Dan Sistem Pengendalian Intern Sebagai Anteseden Kualitas Laporan Keuangan Pemerintah Daerah. STAR - Study \& Accounting Research XI (1): 15-32.

Susilawati, Heri. 2016. Pengaruh Peran Bendahara Pengeluaran Dan Pejabat Penatausahaan Keuangan Skpd Terhadap Kualitas Laporan Keuangan Pemerintah Daerah Di Kabupaten Sigi. Jurnal Katalogis, 4 (6): 12-21.

Syahputra, Andi. 2017. Pengaruh Kompetensi Sumber Daya Manusia, Penerapan Teknologi Informasi dan Penerapan Standar Akuntansi Pemerintahan terhadap Kualitas Laporan Keuangan (Studi Empiris pada SKPK Kabupaten Bener Meriah). Tesis. Banda Aceh, Universitas Syiah Kuala. 
Vol. 4, No. 06; 2021

ISSN: 2581-4664

Undang-Undang Nomor 15 Tahun 2004 tentang Pemeriksaan Pengelolaan dan Tanggung Jawab Keuangan Negara.

Undang-Undang Nomor 1 Tahun 2004 tentang Perbendaharaan Negara.

Undang-Undang Nomor 17 Tahun 2003 tentang Keuangan Negara.

Word Bank. 2007. Pengelolaan Keuangan Publik di Aceh. Jakarta: The Word Bank.

Yamamoto, K. (2008). What matters in legislators' information use for financial reporting: the case of Japan. (I. da U. de Coimbra, Ed.). Inglês. https: //doi.org/http://dx.doi.org/10.14195/97 8-989-26-0422-0_19

Yuliani, S. 2010. Pengaruh Pemahaman Akuntansi, Pemanfaatan Sistem Informasi Akuntansi Keuangan Daerah dan Peran Internal Audit terhadap Kualitas Laporan Keuangan Pemerintah Daerah (Studi Empiris pada Pemerintah Kota Banda Aceh). Jurnal Telaah dan Riset Akuntansi, 3 (2): 206-220.

Yusniyar, Darwanis \& Abdullah, Syukriy. 2016. Pengaruh Penerapan Sistem Akuntansi Pemerintahan Dan Pengendalian Intern Terhadap Good Governance Dan Dampaknya Pada Kualitas Laporan Keuangan (Studi Pada Skpa Pemerintah Aceh). Jurnal Magister Akuntansi Pascasarjana Universitas Syiah Kuala, 5 (2): 100-115.

Zainuddin. 2020. Pengaruh pengembangan kapasitas sumber daya manusia, pengendalian intern dan pemanfaatan teknologi informasi terhadap kualitas pelaporan keuangan di Kabupaten Aceh Jaya. Tesis. Banda Aceh, Universitas Syiah Kuala.

Zeyn, Elvira. 2011. Pengaruh Good Governance dan Standar Akuntansi Pemerintahan Terhadap Akuntabilitas Keuangan dengan Komitmen Organisasi Sebagai Pemoderasi. Jurnal Akuntansi. Bandung - Jawa Barat: Universitas Pasundan. 